\title{
Comparative Application of PLS and PCR Methods to Simultaneous Quantitative Estimation and Simultaneous Dissolution Test of Zidovudine - Lamivudine Tablets
}

\section{Özgür Üstündağ, ${ }^{1} *$ Erdal Dinç, ${ }^{1}$ Nurten Özdemir ${ }^{2}$ and M. Günseli Tilkan ${ }^{2}$}

${ }^{1}$ Department of Analytical Chemistry, Faculty of Pharmacy, Ankara University, 06100 Tandoğan, Ankara, Turkey

${ }^{2}$ Department of Pharmaceutical Technology, Faculty of Pharmacy, Ankara University, 06100 Tandoğan, Ankara, Turkey

* Corresponding author: E-mail: ustundag@ pharmacy.ankara.edu.tr

Tel: +90 3122033173, Fax: +903122131080

Received: 30-09-2014

\begin{abstract}
In the development strategies of new drug products and generic drug products, the simultaneous in-vitro dissolution behavior of oral dosage formulations is the most important indication for the quantitative estimation of efficiency and biopharmaceutical characteristics of drug substances. This is to force the related field's scientists to improve very powerful analytical methods to get more reliable, precise and accurate results for the quantitative analysis and dissolution testing of drug formulations. In this context, two new application of partial least squares (PLS) and principal component regression (PCR) were applied for the simultaneous quantitative estimation and dissolution testing of zidovudine (ZID) and lamivudine (LAM) in a tablet dosage form. The results obtained in this study strongly encourage us to use them for the quality control, the routine analysis and the dissolution test of the marketing tablets containing ZID and LAM drugs.
\end{abstract}

Keywords: PLS, PCR, chemometrics, Anti-HIV, dissolution

\section{Introduction}

Zidovudine (ZID) or azidothymidine (AZT) has been used for the treatment of HIV/AIDS infectiousness. Its chemical name is 3'-azido-3'-deoxythymidine. ZID is phosphorylated to its active 5'-triphosphate metabolite (ZID triphosphate). ZID triphosphate is inhibition of reverse transcriptase via DNA chain termination after incorporation of the nucleoside analogue. ZID triphosphate is a weak inhibitor of the mammalian DNA polymerase$\alpha$ and mitochondrial DNA polymerase-ã and has been reported to be incorporated into the DNA of cells in culture. Lamivudine (LAM), chemically named (2R,cis)-4amino-1-(2-hydroxymethyl-1,3-oxathiolan-5-yl)-(1H)pyrimidin-2-one or (-)-2',3'-dideoxy, 3'-thiacytidine (3TC) is the (-)-enantiomer of a dideoxy analogue of cytidine. LAM has been used for the treatment of infections with the human immunodeficiency viruses (HIVs) and chronic hepatitis B viruses. LAM is phosphorylated to its active 5'-triphosphate metabolite (LAM triphosphate). The principal mode of action of LAM triphosphate is inhibition of reverse transcriptase via DNA chain termi- nation after incorporation of the nucleoside analogue. LAM triphosphate is a weak inhibitor of mammalian DNA polymerases- $\alpha,-\beta$ and mitochondrial DNA polymerase $-\gamma$ LAM is often given in combination whit ZID in order to provide desirable therapy. In HIV-1 infected MT4 cells, LAM in combination with ZID had synergistic antiretroviral activity. Synergistic activity of ZID and LAM was also shown in a variable-ratio study. ZID and LAM are in a class of medications called nucleoside reverse transcriptase inhibitors.

A review of the literature shows that various conventional analytical methods including spectrophotometry, ${ }^{1-5}$ high performance thin layer chromatography, ${ }^{4}$ high performance liquid chromatography, ${ }^{4-13}$ high performance liquid chromatography-mass spectrometry ${ }^{14}$ and signal processing method ${ }^{15}$ were reported for the analysis of ZID and LAM or their combination with other drugs in tablets, human serum and in drug dissolution studies.

Nowadays, the multivariate calibration models e.g. partial least squares (PLS) and principal component regression (PCR) are very popular chemometric methods to easily quantify the contents of complex samples i.e. biolo- 
gical liquids, environmental samples and commercial dosage forms containing multiple drug substances. ${ }^{16-20}$ Further, more of the chemometric calibration algorithms are applied to all data sets at the different formats such as the UV-VIS spectra, IR spectra, chromatograms, and voltammograms obtained from different analytical instrumentations in order to predict the content of the pharmaceutical samples. Particularly, PLS and PCR approaches are preferable calibration techniques mainly because they provide an efficient quantitative resolution of complex mixtures of drugs. ${ }^{21-33}$

In the work presented in this study, two different chemometric calibration approaches, PLS and PCR were applied for the quantification and dissolution testing of ZID and LAM in commercial tablets. Both PLS and PCR approaches don't require any prior separation step such as extraction and precipitation etc. In the calibration treatments, a concentration data matrix (y - block) and absorbance data matrix ( $\mathrm{x}$ - block) were used for building PLS and PCR calibration equations. The validity or ability of the applied PLS and PCR calibration methods were performed by analyzing the test samples of the related drugs. The 20 mixture samples of ZID and LAM drugs in their different concentration levels were randomly prepared as a training set in the $\mathrm{pH}: 1.2$ buffer solution. The absorption spectra of the calibration set and sample solutions were recorded in the spectral region of 210-320 nm. From the analysis results of the test samples obtained by PLS and PCR methods, percent mean recoveries were found to be $100.4 \%$ and $100.7 \%$ for ZID and $99.5 \%$ and $99.3 \%$ for LAM, respectively. After method validation procedure, the applied PLS and PCR calibration models were used for the quantification and dissolution tests of the commercial samples containing ZID and LAM substances.

\section{Experimental}

\section{1. Instruments and Software}

A Shimadzu UV-2520 double beam UV-Vis spectrophotometer connected to a computer loaded with Shimadzu UVPC software was used to record the UV absorption spectra of calibration set and commercial samples. A special algorithm written in Matlab and Microsoft Excel software were used for the spectral data treatments, statistical calculations and spectral transformation procedure. Dissolution test procedure was carried out by using USP Apparatus II-Palet Method (AYMES dissolution test apparatus, Aymes Ind., Umraniye, Istanbul, Turkey).

\section{2. Commercial Tablet Formulation}

A commercial pharmaceutical preparation named Combivir ${ }^{\circledR}$ tablet (produced by Glaxo Smith Kline) con- sisting of $300 \mathrm{mg}$ ZID and $150 \mathrm{mg}$ LAM per tablet was investigated. Active compounds, ZID and LAM were kindly denoted from the national Pharm. Industry firms, Turkey.

\section{3. Preparation of Standard Solutions}

The standard stock solutions of ZID and LAM were prepared by dissolving $20 \mathrm{mg}$ of each substance in $100 \mathrm{~m}$ $\mathrm{L}$ of the $\mathrm{pH} 1.2$ buffer solution. A calibration set containing ZID and LAM in the working concentration range of $0.0-70.0 \mu \mathrm{g} / \mathrm{mL}$ for ZID and LAM, respectively. For the ability and validity testings of the applied chemometric methods, the test samples of ZID and LAM in the linear concentration ranges as well as calibration were prepared by using the same stock solutions.

\section{4. Chemometric Methods}

\section{Partial Least Squares}

The PLS calibration technique based on the orthogonalized PLS algorithm developed by Wold and extensively discussed by Martens and Naes ${ }^{19}$ involves simultaneously the independent and the dependent variables on the data compression and decomposition processes. The absorbance data (independent variable, $A$ ) and the concentration data matrix (dependent variable, $C$ ) are mean centred and denoted by the data matrix $A_{o}$ and the vector (or matrix) $C_{o}$, respectively. Based on data matrix $A_{o}$ and vector $C_{o}$, the orthogonalized PLS calibration is based on the decomposition of both concentration and the absorbance data matrix into latent variables:

$$
\begin{aligned}
& A=T P^{T}+E \\
& C=U Q^{T}+F
\end{aligned}
$$

The matrix $A$, which is related to absorbance data is decomposed into a matrix $T$ (the score matrix) and a matrix $P^{T}$ (the absorbance loadings matrix) plus an error matrix $E$. In the equation 2, the matrix $C$, which is related to concentration data is decomposed into $U$ and $Q$ (the concentration loadings). The goal of the PLS method is to minimize the norm of $F$ (error matrix) in such a way to keep the correlation between $A$ and $C$ by the inner relation $U=B T$.

The linear regression (Equation 3) is used for the quantitative estimation of the compounds in the samples.

$C_{\text {prediction }}=B \times A_{\text {sample }}$

The vector, $B$ is given as Equation 4

$$
B=W \times\left(P^{T} \times W\right)^{-1} \times Q
$$

where $W$ is a weight matrix. 


\section{Principal Component Regression}

Principal component regression approach has two steps. In the first step, the eigenvalues and their eigenvectors are obtained from the covariance square matrix of the mean-centred absorbances represents the first step of PCR. By using the cross-validation in the calibration step, the principal components (or the eigenvectors) corresponding to the large eigenvalues are selected to compute $A_{p r o j}$ (new axes) in the second step.

The mathematical basis of the PCR model is given by

$$
A_{\text {proj }}=V C^{T} A
$$

Here, $A_{p r o j}$ is the matrix containing the new coordinates, $A$ represents the original absorbance matrix and $V C^{T}$ is the matrix containing the basis vectors (principal components), one column for each factor retained. If we know the matrix $A_{\text {proj }}$ we find, after some simple calculations, the unknown concentration matrix using the following formula:

$$
C=F A_{\text {proj }}
$$

where $F$ represents the calibration coefficient for the obtained linear equation system.

Mathematical treatments of the PCR and PLS algorithims was performed by means of a special algorithm written in Matlab 7.1 software.

\section{Results and Discussion}

The UV absorption spectra of drugs (ZID and LAM) and their mixtures were recorded between the wavelength range 210-320 $\mathrm{nm}$, respectively. It was observed that the analysed substances gave the strong overlapping spectra in the same wavelength region as indicated in Figure 1. In this case, it is not possible to use a direct absorbance measurement technique for the simultaneous analysis and dissolution testing of ZID and LAM in their tablets. In order to solve this problem we focused mainly on the application of PLS and PCR calibration methods for the simultaneous quantification and dissolution testing of ZID and LAM. These chemometric analysis and dissolution tests were explained below in detail.

\section{1. Application of the PLS and PCR Methods}

As explained above, the concentration set of the mixture samples containing ZID and LAM in the working range of $0.0-70.0 \mu \mathrm{g} / \mathrm{mL}$ was prepared and indicated in Table 1. This calibration set was considered as $\mathrm{y}-$ block, which corresponds to the matrix $\mathrm{C}$. The UV spectra of the calibration set samples were recorded in the spectral region $210-320 \mathrm{~nm}$ with the intervals of $\Delta \lambda=0.1 \mathrm{~nm}$. The spectral data of the calibration samples were expressed as $\mathrm{x}$ - block corresponding to an absorbance data matrix. In the calibration step, the PLS and PCR calibration algorithms were applied to the relationship between the calibration data matrix and the absorbance data matrix. In the next steps, the building PLS and PCR calibration models were used to quantify the concentration of each active compound in commercial tablet, dissolution samples and other samples.

In the case of the PLS calibrations, the actual and predicted concentrations for ZID and LAM were plotted and shown in Figure 2. In the same way, for the PCR calibration, actual and predicted concentrations for ZID and LAM were graphically presented in Figure 4 . As can be seen in figures, good correlation coefficients were reported.

In the prediction steps of the applied PLS and PCR approaches, Figure 3. and 5. shows the plots of the actual and predicted concentrations using PLS and PCR, respectively.

\begin{tabular}{|c|c|c|c|c|c|}
\hline \multirow{2}{*}{ No. } & \multicolumn{2}{|c|}{$\mu \mathrm{g} / \mathrm{mL}$} & \multirow{2}{*}{ No. } & \multirow{2}{*}{$\begin{array}{c}\mu \mathrm{g} / \mathrm{mL} \\
\text { ZID }\end{array}$} & \multirow{2}{*}{ LAM } \\
\hline & ZID & LAM & & & \\
\hline 1 & 0.0 & 2.0 & 12 & 2.0 & 24.0 \\
\hline 2 & 48.0 & 2.0 & 13 & 0.0 & 50.0 \\
\hline 3 & 2.0 & 0.0 & 14 & 20.0 & 24.0 \\
\hline 4 & 48.0 & 10.0 & 15 & 50.0 & 0.0 \\
\hline 5 & 0.0 & 20.0 & 16 & 30.0 & 24.0 \\
\hline 6 & 48.0 & 30.0 & 17 & 0.0 & 70.0 \\
\hline 7 & 10.0 & 0.0 & 18 & 50.0 & 24.0 \\
\hline 8 & 48.0 & 50.0 & 19 & 70.0 & 0.0 \\
\hline 9 & 0.0 & 30.0 & 20 & 70.0 & 24.0 \\
\hline 10 & 48.0 & 70.0 & & & \\
\hline 11 & 30.0 & 0.0 & & & \\
\hline
\end{tabular}

Table 1. Calibration set for PLS and PCR calibrations methods

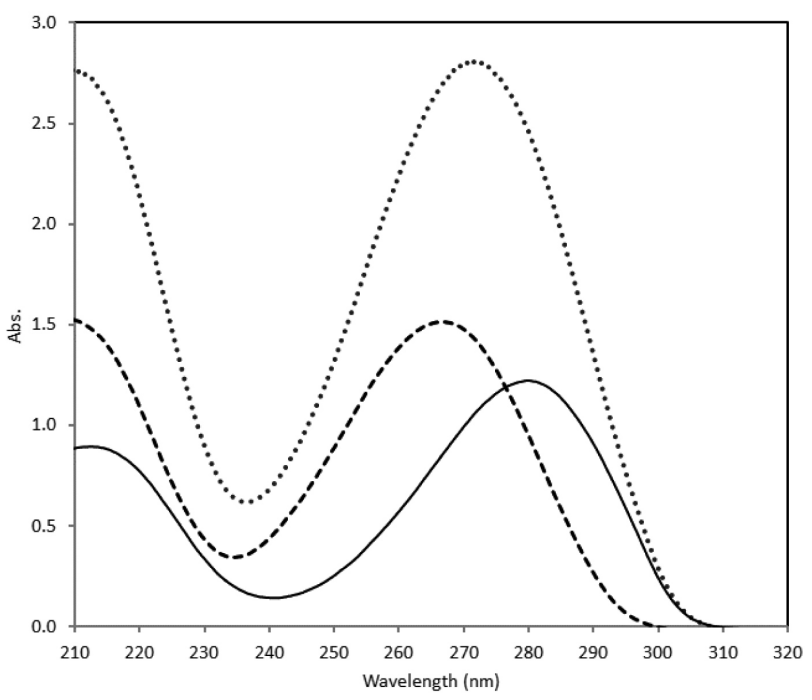

Figure 1. The UV spectra of $40 \mu \mathrm{g} / \mathrm{mL}$ ZID (---), $20 \mu \mathrm{g} / \mathrm{mL}$ LAM (-) and their mixture ( $\cdots)$ in $\mathrm{pH} 1.2$ buffer. 
a)

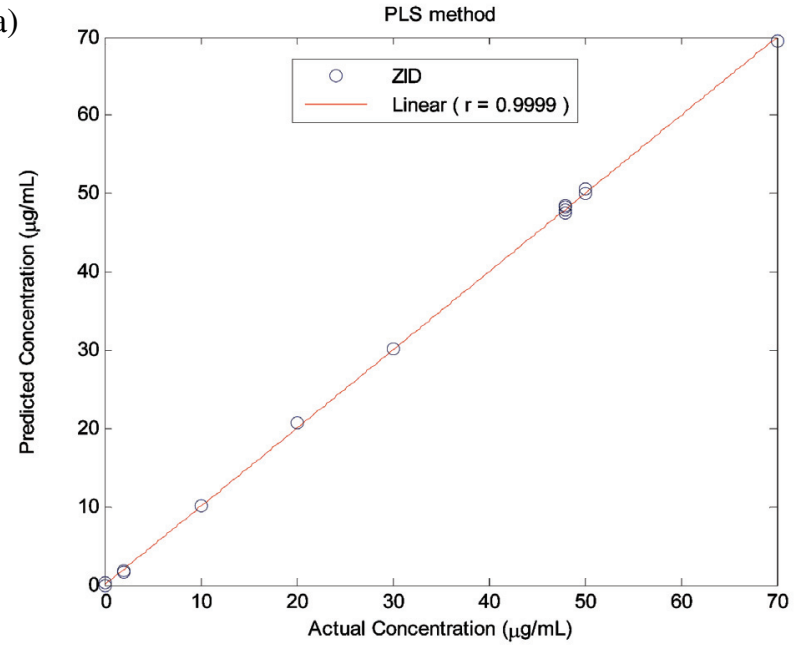

b)

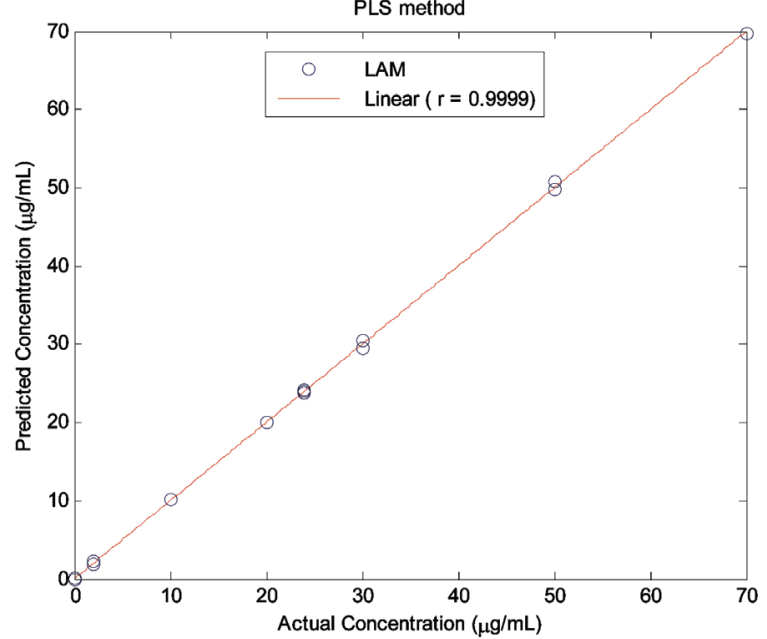

Figure 2. Plot of the actual and predicted concentrations in the calibration step by using the PLS method with four components for ZID (a) and LAM (b) drugs

a)

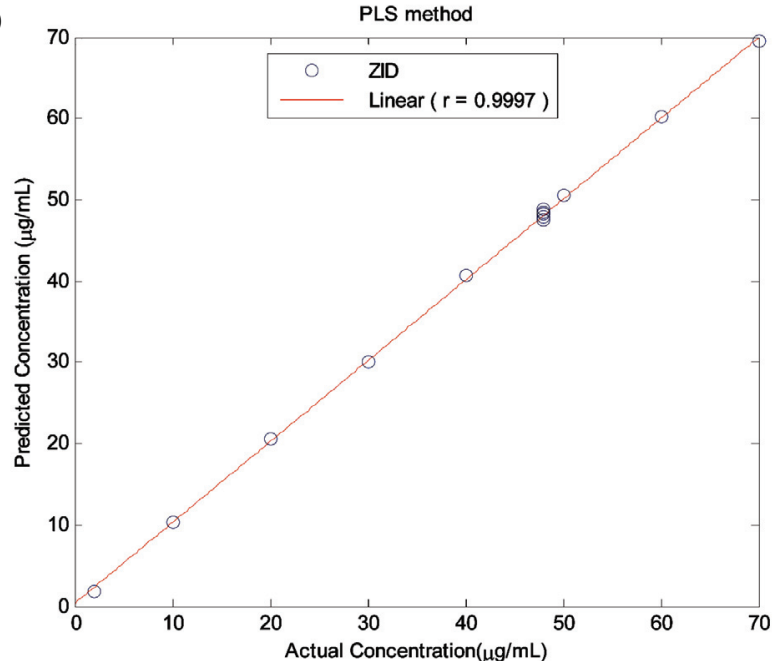

b)

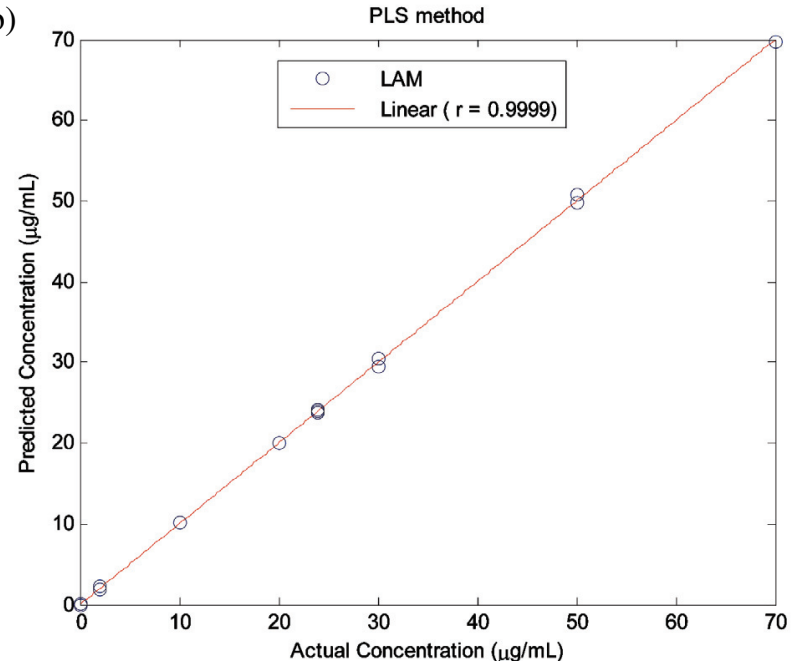

Figure 3. Plot of the actual and predicted concentrations in the prediction step by using the PLS method with four components for ZID (a) and LAM (b) drugs

a)

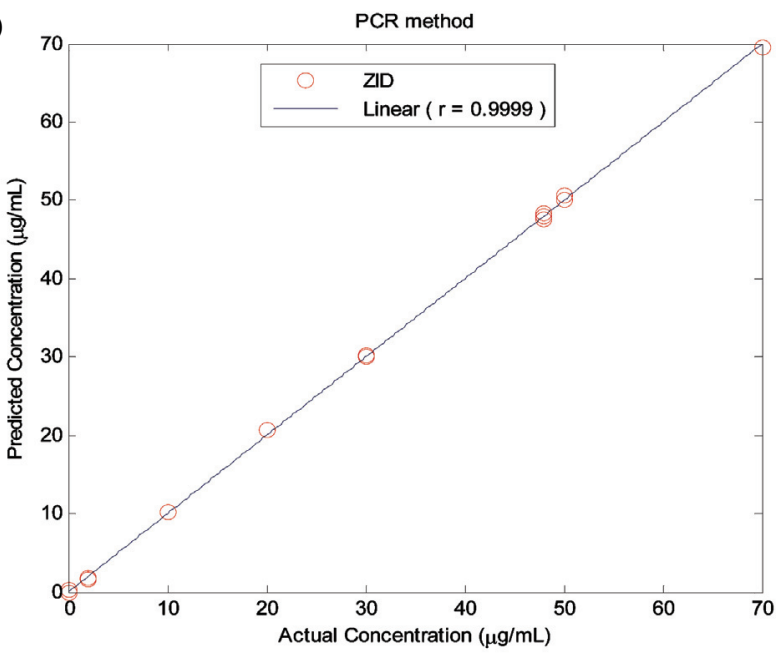

b)

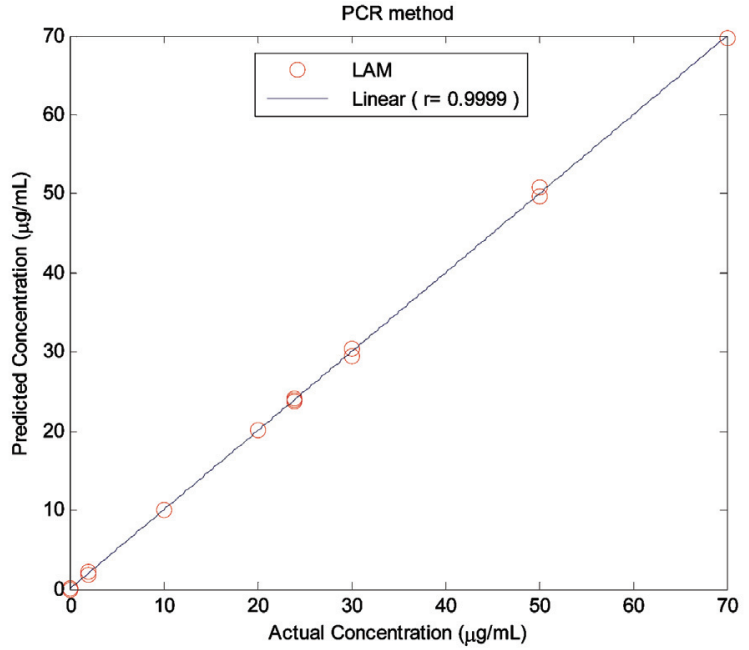

Figure 4. Plot of the actual and predicted concentrations in the calibration step by using the PCR method with four components for ZID (a) and LAM (b) drugs 

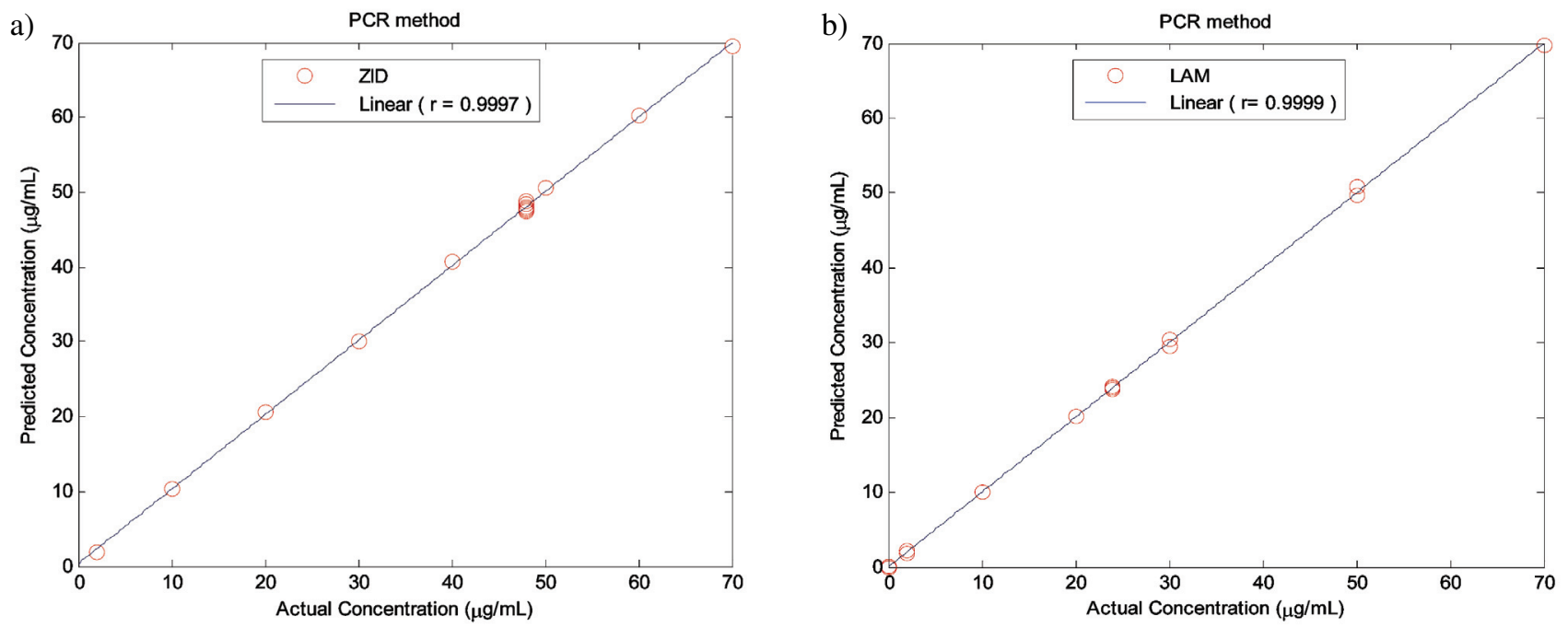

Figure 5. Plot of the actual and predicted concentrations in the prediction step by using the PCR method with four components for ZID (a) and LAM (b) drugs

\section{2. Analytical Validation of the Signal Processing Methods}

Prior to the application of the PLS and PCR calibrations to the quantification and dissolution testing of ZID and LAM from tablets, the performance and ability of the proposed chemometric calibrations were tested by analyzing the test samples (or validation samples) containing ZID -LAM mixtures prepared as listed in Table 2. For the estimation of the calibration methods, the analysis results were computed for the test samples. As can be seen in this table, the applied PLS and PCR models provided us higher analytical method performance and applicability with better precision and accuracy for the recovery studies. In addition, the method ability was evaluated using the standard error of prediction (SEP). In the calibration step, for both PLS and PCR approaches, first four factors were found to be suitable to get minimal standard error of calibration

Table 2. Recovery data obtained by applying the PLS and PCR methods to the analysis of ZID and LAM in the synthetic mixtures

\begin{tabular}{|c|c|c|c|c|c|c|c|c|c|c|}
\hline \multirow[b]{3}{*}{ No. } & \multirow{2}{*}{\multicolumn{2}{|c|}{ Mixture }} & \multicolumn{4}{|c|}{ PLS-method } & \multicolumn{4}{|c|}{ PCR-method } \\
\hline & & & \multicolumn{2}{|c|}{ Found } & \multicolumn{2}{|c|}{ Recovery (\%) } & \multicolumn{2}{|c|}{ Found } & \multicolumn{2}{|c|}{ Recovery (\%) } \\
\hline & ZID & LAM & ZID & LAM & ZID & LAM & ZID & LAM & ZID & LAM \\
\hline 1 & 48 & 2 & 48.30 & 1.91 & 100.6 & 95.5 & 48.30 & 1.90 & 100.6 & 95.0 \\
\hline 2 & 48 & 10 & 48.00 & 10.18 & 100.0 & 101.8 & 48.10 & 10.09 & 100.2 & 100.9 \\
\hline 3 & 48 & 20 & 48.80 & 20.13 & 101.7 & 100.7 & 48.80 & 20.15 & 101.7 & 100.8 \\
\hline 4 & 48 & 30 & 47.60 & 29.56 & 99.2 & 98.5 & 47.70 & 29.55 & 99.4 & 98.5 \\
\hline 5 & 48 & 40 & 47.60 & 39.81 & 99.2 & 99.5 & 47.80 & 39.80 & 99.6 & 99.5 \\
\hline 6 & 48 & 50 & 48.50 & 50.80 & 101.0 & 101.6 & 48.40 & 50.91 & 100.8 & 101.8 \\
\hline 7 & 48 & 60 & 47.50 & 60.11 & 99.0 & 100.2 & 47.60 & 60.21 & 99.2 & 100.4 \\
\hline 8 & 48 & 70 & 47.90 & 69.71 & 99.8 & 99.6 & 48.00 & 69.60 & 100.0 & 99.4 \\
\hline 9 & 2 & 24 & 1.98 & 23.75 & 99.0 & 99.0 & 1.91 & 23.71 & 95.5 & 98.8 \\
\hline 10 & 10 & 24 & 10.20 & 23.70 & 102.0 & 98.8 & 10.40 & 23.50 & 104.0 & 97.9 \\
\hline 11 & 20 & 24 & 20.60 & 23.98 & 103.0 & 99.9 & 20.70 & 23.97 & 103.5 & 99.9 \\
\hline 12 & 30 & 24 & 30.10 & 23.87 & 100.3 & 99.5 & 30.40 & 23.86 & 101.3 & 99.4 \\
\hline 13 & 40 & 24 & 40.70 & 23.90 & 101.8 & 99.6 & 41.00 & 23.88 & 102.5 & 99.5 \\
\hline 14 & 50 & 24 & 50.60 & 24.08 & 101.2 & 100.3 & 50.80 & 24.11 & 101.6 & 100.5 \\
\hline 15 & 60 & 24 & 60.20 & 23.97 & 100.3 & 99.9 & 61.00 & 23.90 & 101.7 & 99.6 \\
\hline 16 & 70 & 24 & 69.60 & 23.75 & 99.4 & 99.0 & 69.70 & 23.51 & 99.6 & 98.0 \\
\hline \multirow[t]{4}{*}{17} & 48 & 24 & 47.90 & 23.60 & 99.8 & 98.3 & 48.20 & 23.40 & 100.4 & 97.5 \\
\hline & & & & Mean & 100.43 & 99.50 & & & 100.68 & 99.25 \\
\hline & & & & SD & 1.19 & 1.41 & & & 1.93 & 1.59 \\
\hline & & & & RSD & 1.19 & 1.42 & & & 1.92 & 1.60 \\
\hline
\end{tabular}

SD : Standard deviation

RSD : Relative standard deviation 
a)

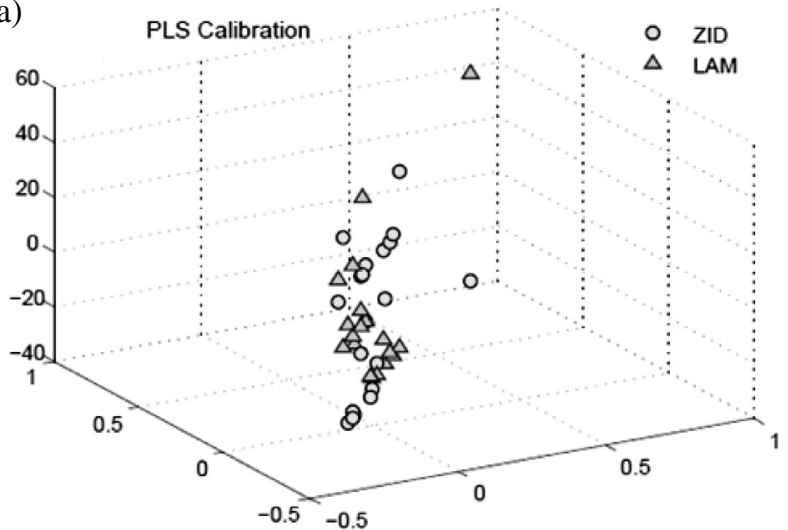

b)

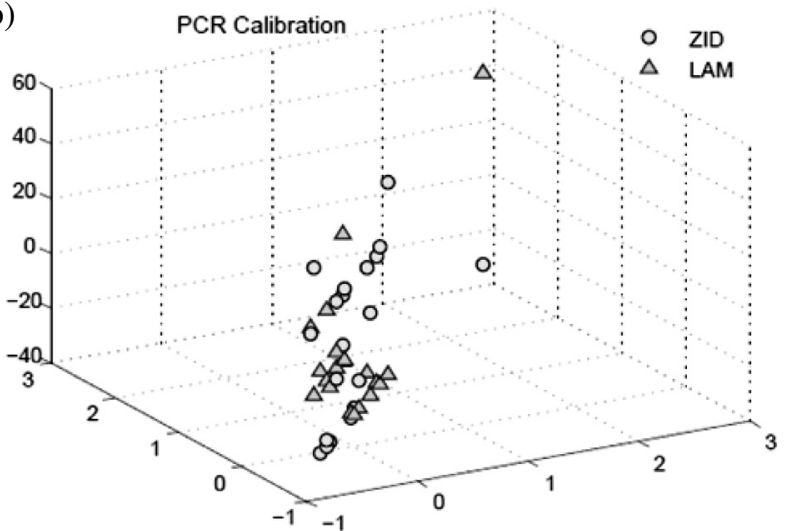

Figure 6. The plots of the predictor variables of the established PLS (a) and PCR (b) models

(SEC) values. The numerical values of SEC and SEP using PLS and PCR with first four factors were calculated as 0.3350 and $0.3321 ; 0.4493$ and 0.4526 for ZID, 0.2769 and 0.2834: 0.2937 and 0.3015 for LAM, respectively.

In order to compare the predictive power of the PLS and PCR models, the predictive variables including the variable importance in projection were illustrated in Figure 6a and $b$. After these results, we concluded that the chemometric PLS and PCR calibrations were very suitable for analysis and dissolution test of two anti-HIV drugs in samples.

\section{3. Tablet Analysis}

The quantitative estimation of ZID and LAM drugs in commercial tablets were carried out by the PLS and

Table 3. Determination results of ZID and LAM in tablets with PLS and PCR methods (300 mg ZID and $150 \mathrm{mg}$ LAM per tablet)

\begin{tabular}{lcrrr}
\hline & & \multicolumn{2}{c}{ mg/tab } & \multicolumn{2}{c}{ PCR } \\
No. & ZID & LAM & ZID & LAM \\
\hline 1 & 300.9 & 150.6 & 300.9 & 150.6 \\
2 & 299.0 & 149.7 & 299.0 & 149.6 \\
3 & 299.1 & 147.9 & 296.4 & 147.9 \\
4 & 301.6 & 148.8 & 297.0 & 148.8 \\
5 & 300.9 & 151.4 & 303.3 & 151.4 \\
6 & 298.6 & 150.5 & 298.7 & 149.8 \\
7 & 298.7 & 150.8 & 298.7 & 150.8 \\
8 & 295.2 & 148.1 & 295.3 & 148.1 \\
9 & 299.3 & 149.3 & 299.4 & 148.9 \\
10 & 302.7 & 151.7 & 302.8 & 151.7 \\
Mean & 299.6 & 149.9 & 299.2 & 149.8 \\
SD & 2.07 & 1.34 & 2.6 & 1.35 \\
RSD & 0.69 & 0.89 & 0.87 & 0.90 \\
SH & 0.65 & 0.42 & 0.82 & 0.43 \\
CL & 1.28 & 0.83 & 1.61 & 0.84 \\
\hline
\end{tabular}

SD : Standard deviation

RSD : Relative standard deviation

SE : Standard error

CL : Confidential limit $(\mathrm{p}=0.05)$
PCR approaches. The assay results of pharmaceutical tablet formulation were shown in Table 3. According to the tablet assay results given in Table 3, no effect of excipients on the analysis was observed in the application of the PLS and PCR methods. In addition, it was observed that the determination results were very close to each other, therefore a good agreement was reported.

\section{4. Dissolution Profiles of Tablets}

After analyzing tablets, the applied PLS and PCR methods were used for the dissolution testing of ZID and LAM from their solid dosage form. In this testing procedure, the dissolution profiles of ZID and LAM in commercial tablets were plotted and presented in Figure 7. For the dissolution test procedure, USP Apparatus II - Palet method was used for the collection of the dissolution samples during 20 minutes. We used pH 1.2 buffer solution as dissolution medium. The absorption spectra of the samples were plotted between 210-320 $\mathrm{nm}$. The measured absorbance values obtained from the above spectra of dissolution samples were placed into the equations of PLS and PCR and the quantities of ZID and LAM in collected samples were computed. Approximately $90 \%$ of both drugs were dissolved within the first $10 \mathrm{~min}$. Both PLS and PCR methods gave us comparable dissolution profiles for ZID and LAM from tablets.

\section{Conclusion}

In this study, two new applications of the chemometric approaches based on PLS and PCR calibrations were used for the simultaneous quantitative estimation and dissolution test of ZID and LAM in tablets. In the application of the PLS and PCR approaches for the dissolution testing of the solid dosage form, the dissolution profiles of ZID and LAM from tablets were obtained to reveal the pharmaceutical behavior of the commercial tablets containing re- 

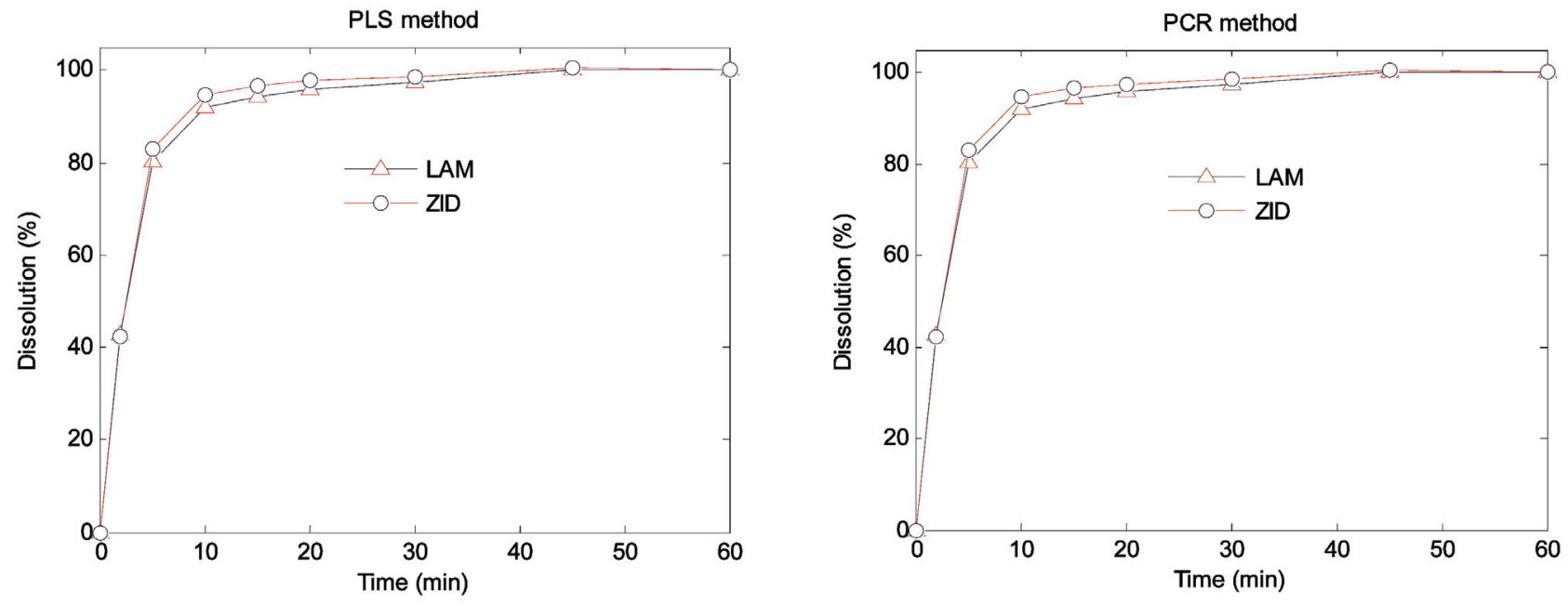

Figure 7. Dissolution profiles of the ZID and LAM drugs by applying the proposed PLS (a) and PCR (b) methods with four components

lated drugs. We concluded that these applied chemometric calibrations were very suitable way to determine the contents of ZID and LAM in their samples. A good agreement was reported for the results of the analysis and dissolution testing of tablets containing ZID and LAM substances.

\section{Acknowledgement}

This study was performed at the Chemometrics Laboratory of Faculty of Pharmacy, which was supported by the scientific research fund of Ankara University (Project Number 10A3336001). The authors would like to thank Ankara University for their support to be completed this study.

\section{References}

1. K. Prakash, P. Narayana Raju, K Shanta Kumari., M.Lakshmi Narasu, E-Journal of Chemistry, 2008, 5, 1159-1164.

2. V. N. L., Y.Sirisha Kiran Kumarrao, M. Chinna Eswaraiah, Int. J. Pharm. Biomed. Res., 2012, 3, 1759-1763.

3. P. B. Mohite, R. B.Pandhare, S. G.Khanage, Advanced Pharm. Bull., 2012, 2, 115-118.

4. S. Anbazhagan, N. Indumathy, P. Shanmugapandiyan, S. Krishnan Sridhar, J. Pharm. Biomed Anal., 2005, 39, 801804. http://dx.doi.org/10.1016/j.jpba.2005.04.044

5. N. Kapoor, S. Khandavilli, R. Panchagnula, J. Pharm. Biomed. Anal., 2006, 41, 761-765.

http://dx.doi.org/10.1016/j.jpba.2006.01.007

6. Z. M. M. Lavra, P. J. R. Neto, R. M. F. Da Silva, F. P. M. De Medeiros, Quim. Nova, 2008, 31, 969-974. http://dx.doi.org/10.1590/S0100-40422008000500005

7. B. Fan, J. T. Stewart, J. Pharm. Biomed. Anal., 2002, 28, 903-908. http://dx.doi.org/10.1016/S0731-7085(01)00708-7

8. A. Joshi, M. C. Adeyeye, J. Pharm. Technology \& Drug Research, 2012, 1, 1-4.
http://dx.doi.org/10.7243/2050-120X-1-4

9. P. Djurdjevic, A. Laban, S. Markovic, M. Jelikic-Stankov, Anal. Lett., 2004, 37, 2649-2667.

http://dx.doi.org/10.1081/AL-200031946

10. N. Hari Krishnan, V. Gunasekaran, C. Roosewelt, V. K. Meher, K. Kalaivani, V. Ravichandiran, Asian Journal of Chemistry, 2008, 20, 2551-2556.

11. B. Jayakar, M. Kumar, C. Saravanan, M. V. Kumudhavalli, J. Chem. Pharm. Res., 2010, 2, 478- 481.

12. N. Kapoor, S. Khandavilli, R. Panchagnula, Anal. Chim. Acta, 2006, 570, 41-45.

http://dx.doi.org/10.1016/j.aca.2006.03.107

13. A. Savaser, S. Goraler, A. Tasoz, B. Uslu, H. Lingeman, S. A. Ozkan, Chromatographia, 2007, 65, 259-265. http://dx.doi.org/10.1365/s10337-006-0166-6

14. K. B. Kenney, S. A. Wring, R. M. Carrb, G. N. Wells, J. A. Dunn, J. Pharm. Biomed. Anal., 2000, 22, 967-983. http://dx.doi.org/10.1016/S0731-7085(00)00248-X

15. E. Dinç, N. Özdemir, Ö. Üstündağ, M.G. Tilkan, Chem. \& Pharm. Bull., 2013, 61 (12), 1220- 1227. http://dx.doi.org/10.1248/cpb.c13-00284

16. P. Kramer, Chemometric Techniques in Quantitative Analysis, Marcel Dekker. Inc.: New York, 1998. http://dx.doi.org/10.1201/9780203909805

17. K. R. Beebe, K. R. Kowalski, Anal. Chem. 1987, 59, 1007A1017A. http://dx.doi.org/10.1021/ac00144a725

18. M. J. Adams, Chemometrics in Analytical Spectroscopy, The Royal Society of Chemistry, Thomas, Graham House, Science Park: Cambridge, 1995.

19. H. Marthens, T. Naes, Multivariate Calibration, John Wiley and Sons Ltd: Chichester, UK, 1991.

20. P. Geladi, B. R. Kowalski, Anal.Chim.Acta, 1986, 185, 1-17. http://dx.doi.org/10.1016/0003-2670(86)80028-9

21. E. Dinç, D. Baleanu, J. AOAC Int. 2004, 87(2), 360-365.

22. E. Dinç, D. Baleanu, Ö. Üstündağ, Spectr. Lett., 2003, 36, 341-355.

http://dx.doi.org/10.1081/SL-120024583 
23. E. Dinç, F. Arslan, D. Baleanu, Rev. Roum. Phys., 2008 , 53(8), 607-611.

24. E. Dinç, D. Baleanu, J. Food Drug Anal., 2007, 15(2), 109-117.

25. E. Dinç, K. Süha, T. Dodanay, D. Baleanu, J. Pharm. Biomed. Anal., 2007, 44, 991-995.

http://dx.doi.org/10.1016/j.jpba.2007.03.027

26. A. Afkhami, T. Madrakian, M. Abbasi-Tarighat, Food Chem., 2008, 109(3), 660-669.

http://dx.doi.org/10.1016/j.foodchem.2007.12.078

27. A. Afkhami, M. Abbasi-Tarighat, Talanta, 2009, 78(2), 424431. http://dx.doi.org/10.1016/j.talanta.2008.11.032

28. B. Ghasemi, A. Niazi, E. Nadaf, A. Mordai, Anal. Lett., 2004, 37, 2609-2623.

http://dx.doi.org/10.1081/AL-200029389
29. J. Ghasemi, A. Niazi, S. Ghobadi, J. Pharm. Chem. 2005, 39(12), 671-675. http://dx.doi.org/10.1007/s11094-006-0044-4

30. H. Khajehsharifi, Z. Eskandari, A. Asadipour, Drug Testing Anal., 2010, 2(3-4), 162-167. http://dx.doi.org/10.1002/dta.118

31. S. S. Abbas, H. E. Zaazaa, M. Abdelkawy, M. M. Abdelrahman, Drug Testing Anal., 2010, 2(3-4),168-181.

32. M. A. Hegazy, M. R. El-Ghobashy, A. M. Yehia, A.A. Mostafa, Drug Testing Anal., 2009, 1(7-8), 339-349. http://dx.doi.org/10.1002/dta.60

33. M. A. El-Sayed, M. A. Mohammad A., Drug Testing Anal., 2009, 1(5-6), 228-233. http://dx.doi.org/10.1002/dta.37

\section{Povzetek}

Pri strategiji razvoja novih farmacevtskih izdelkov in generičnih farmacevtskih izdelkov je hkratno spremljanje in-vitro raztapljanja oralnih farmacevtskih oblik najbolj pomembna indikacija za kvantitativno oceno učinkovitosti in biofarmacevtskih karakteristik aktivnih učinkovin. Zaradi tega so tudi znanstveniki s sorodnih področij prisiljeni izboljševati učinkovite analizne metode, da bi dobili bolj zanesljive, natančne in točne rezultate za kvantitativno analizo in spremljanje raztapljanja farmacevtskih oblik. V tem kontekstu smo na novo uporabili metodo delnih najmanjših kvadratov (partial least squares, PLS) in metodo regresije glavnih komponent (principal component regression, PCR) za hkratno kvantitativno oceno in spremljanje raztapljanja zidovudina (ZID) in lamivudina (LAM) v farmacevtski obliki tablet. Rezultati iz te študije nas spodbujajo, da te metode uporabimo za kontrolo kvalitete, rutinsko analizo in spremljanje raztapljanja pri trženju tablet z učinkovinama ZID in LAM. 